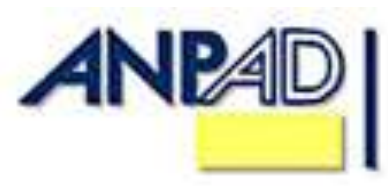

Available online at

http://www.anpad.org.br/bar

BAR, Rio de Janeiro, v. 12, n. 2, art. 1,

pp. 129-149, Apr./June 2015

http://dx.doi.org/10.1590/1807-7692bar2015140055

(oc) EYYNo

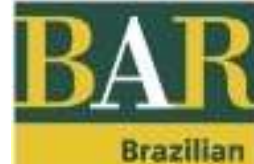

Administration

Review

\title{
When a Thousand Words Are (Not) Enough: An Empirical Study of the Relationship between Firm Performance and Attention to Shareholders
}

Received 16 September 2014; received in revised form 14 January 2015; accepted 20 February 2015; published online 12 June 2015.

Editor's note. Ricardo C. Gomes served as Action Editor for this article. 


\begin{abstract}
The aim of this study is to concurrently test the explanatory power of the attention-based view (ABV) of the firm and of the resource dependence theory (RDT). We propose a conceptual model of attention to shareholders based on assumptions of both ABV and RDT. We test these hypotheses using a unique dataset, consisting of contentanalyzed data on attention allocation for 313 firms from 24 different countries. Our research findings highlight the complementary nature of the RDT and ABV and add to the literature about attention, providing empirical evidence and theoretical explanation for the scarcely explored relationship between firm performance and organizational attention.
\end{abstract}

Key words: attention-based view; financial performance; resource dependence; shareholder; stakeholder theory. 


\section{Introduction}

Since the introduction of resource dependence theory (RDT) (Pfeffer \& Salancik, 1978), scholars interested in understanding the linkages between organizations and their environment widely used RDT, and stakeholder management scholars have likewise followed suit. The core of RDT lies in the idea that organizations are not self-sufficient and, as a result, they must manage their interdependences with shareholders and stakeholders to gain access and control over required resources and information (Pfeffer \& Salancik, 1978). Resource dependence theory is thus a likely candidate for providing the conceptual backbone for stakeholder theory, as it offers constructs and working hypotheses relevant for the analysis of firm strategies and performance under conditions of (partial) dependence on external stakeholder groups.

But whereas RDT can fruitfully be used to explain phenomena pertinent to stakeholder management, such as co-optation through board structures (Pfeffer \& Salancik, 1978) and the prioritization of stakeholders (Mitchell, Agle, \& Wood, 1997), the theory is limited in at least two ways. First, RDT has been criticized for being a somewhat deterministic theory, focused predominantly on how firms respond to environmental constraints. Second, RDT focuses predominantly on the task environment and on task-related dependencies, whereas institutional environments are also a source of pressure on organizations. Together, these problems impose limitations to the explanatory power of RDT (Casciaro \& Piskorski, 2005).

Additionally, RDT does not provide an explanation of how organizations cope with the multiplicity of interdependences, or as Finkelstein (1997) puts it, what comes first. In spite of recognizing the multiplicity of internal and external environmental stimuli affecting organizations and also the numbered constraints on organizational behavior such as physical realities, social influences, personal preferences and cognitive capacities (Pfeffer \& Salancik, 1978), a resource dependence approach focuses its explanation of the linkage between environments and organizations on the presence of structures and information systems as enablers of environment enactment, not exploring internal linkages which also account for a full understanding of organizational moves. Therefore, stakeholder theory could benefit considerably from further reinforcement by different theoretical perspectives, to offset and complement its traditional indebtedness to RDT.

In this paper, we propose the attention-based view (ABV) as a promising complementary framework for the analysis of instrumental stakeholder relationships. While the ABV is also in an early stage of development (Sonpar \& Golden-Biddle, 2008), it does contain some interesting features that could greatly advance stakeholder management. First, it considers both environmental and organizational factors, making it less of a black-box theory than RDT. Second, ABV is decidedly a managerial theory, as it is rooted in an analysis of managerial roles as an explanation for organizational outcomes. An ABV perspective on organizational moves suggests what decision makers do depends on their focus of attention whereas RDT say what decision makers do depends on the interdependences affecting the focal organization. In both perspectives, attention structures are central determinants for organizational behavior because they provide cues to decision makers on how to respond to environmental stimuli (Ocasio, 1997; Pfeffer \& Salancik, 1978). However, an attention based view of the firm offers a linkage and provides an explanation on how organizational structures are related to managerial cognition (Barnett, 2008); a missing link in RDT.

The aim of this study is to test the explanatory power of the attention-based view of the firm against resource dependence theory. By proposing a model of attention to shareholders based on assumptions of both ABV and RDT, our study provides four contributions. First, we provide a concurrent test of explanations for attention to shareholders based on a resource dependence perspective and attention-based view using content analyzed data from letters to shareholders. This source of data has been widely used in research about organizational attention (Abrahamson \& Hambrick, 1997; Cho \& Hambrick, 2006; D’Aveni \& McMillan, 1990; Levy, 2005; Yadav, Prabhu, \& Chandy, 2007) but not necessarily in research testing RDT. We also contribute to the literature on impression management 
providing an alternative explanation for the content of public accounts of organizations. Although annual reports in general, and letters to shareholders more specifically, can be seen as a privileged communication channel to manage external impressions about organizations (Abrahamson \& Park, 1994; Staw, McKechnie, \& Puffer, 1983) these channels are also relevant governance channels which reflect important concrete and contextual aspects of the organization's attention process (Ocasio \& Joseph, 2005, 2006). Third, we contribute to the development of the ABV by providing an explanation for some of the mechanisms "of how the firm as a cultural and social system is shaped by the environment of action" (Ocasio, 1997, p. 193), which are not explicitly addressed in the original model. Finally, we also add to the literature of attention by providing empirical evidence and a theoretical explanation of the almost unexplored relationship between financial performance and organizational attention.

The paper is structured as follows. In the next section we present our conceptual model combining RDT and ABV to explain firms' attention to stakeholders. We believe these two literature streams can advance studies about stakeholder management. Following our theory and hypotheses section, we introduce and explain our methodological approach discussing our primary data source (i.e., content analysis of 313 letters to shareholders, derived from 410 public listed firms in 24 countries), sample, variables and statistical model. Next, we present and discuss the results of the empirical tests of the proposed conceptual model. Lastly, we discuss our findings revealing its implications, considering some of the study limitations and highlighting its contributions.

\section{Theory and Hypotheses}

Resource dependence theory develops from the principle that organizations are unable to produce and generate all necessary resources for their operations and survival (Emerson, 1962; Pfeffer \& Salancik, 1978; Thompson, 1967). As a consequence, firms enter in exchange relationships to obtain necessary resources. On the one hand, these transactions with resource providers guarantee firms' operations. On the other hand, however, they increase external dependencies. Thus, dependency is the basic concept available to researchers trying to explain organizational outcomes.

According to this literature, organizations are embedded in environments that are stocks of resources (White, 1974) and dependence is the basic concept available to researchers who try to explain organizational outcomes. It is the inability of firms to generate their factors for production that forces them to engage in transactions with other organizations, creating external dependencies which ultimately explain phenomena like joint ventures, mergers, board of director composition, boards interlocks and executive succession (Pfeffer \& Salancik, 1978). The lack of resources can vary from raw materials and equipments to skills and knowledge and the higher the need for a certain resource, the higher the likelihood of exchange.

An important aspect of resource dependence theory is its emphasis on the contingent nature of external dependencies. According to RDT, the value of a resource is not inherent, but given by the exchange relationship. Thus, the value of a resource is a direct function of its utility to a firm's operations, and the extent to which that resource is necessary for the firm to operate and survive. These two interrelated aspects of RDT suggest its close affinity with stakeholder theory since both theories focus on the external interdependencies and criticality of resources of the focal firm. However, whereas instrumental stakeholder theory favors the managers' role (Jones, 1995), RDT framework suggests there is limited managerial discretion over the external environment. In spite of the constraints imposed on decision-making by the environment, Pfeffer (1981) identifies social construction as the ultimate role of managerial action. The boundaries created by critical dependencies to the organization limit managerial discretion (Pfeffer \& Salancik, 1978). Nevertheless, resource dependence scholars suggest that managers are able to manipulate external environments and have an influence on them (Pfeffer, 1981). 
Arguments in favor of the symbolic role of managerial action are in line with the attention-based view $(\mathrm{ABV})$ of the firm, which suggests that organizational responses, as social constructions, are structured by organizational attention (Ocasio, 1995). Accordingly, much of what we recognize as organizational behavior reflects decision-makers' interpretations. Taking this connection between both theories as our starting point, we argue that $\mathrm{ABV}$ can fill in an important opening in the literature of RDT and propose a conceptual model to explain how firms attend to stakeholders. The model intends to provide a multilevel framework that considers not only managerial discretion but also internal and external mechanisms and that has the potential to advance stakeholder management.

\section{Hypotheses: firm level antecedents}

From a purely economic standpoint, antecedents of organizational attention to firms' capital providers are based on resource dependence propositions. Accordingly, organizations are more likely to pay attention to capital providers that control resources critical to organizations' operations and survival. The degree of attention paid to a resource provider varies between organizations that are more or less dependent upon the resource in question. Resource dependence theory proposes that dependencies on the external environment predict organizational structure and outcomes (Pfeffer \& Salancik, 1978). According to $\mathrm{ABV}$, cognition and action are not predictable on the basis of individual characteristics, but are consequences of the situations in which decision-makers find themselves, such that attention is linked to the immediate context in which cognition and action are situated (Hung, 2005). Consequently, various factors influence organizational attention (Cho \& Hambrick, 2006; Levy, 2005; Yadav et al., 2007). Although the ABV assumes that it is the individual who ultimately pays attention, it proposes that decision-makers' focus of attention (principle of focus of attention) is situated and dependent upon the context (principle of situated attention) and the organizational structure (principle of structural distribution of attention). Therefore, organizational attention, in general, and attention to stakeholders, more specifically, is contingent on multiple environmental, organizational and individual aspects.

From a purely resource dependence perspective, increased complexity accompanies increased size, which, in turn, brings about additional critical dependencies. Conversely, larger organizations might also be more powerful, thereby increasing their insulation capacity. Hence, pressures are heavily felt in large organizations and, yet, these organizations could also have relational power dependent on the asymmetry of interpedencies (Drees \& Heugens, 2013). ABV complements RDT by suggesting that attention structures and governance channels direct organizational attention by setting rules and creating policies, procedures and guidelines. Consequently, specific channels of communication will direct attention according to their very specific rules and routines. For instance, letters to shareholders (as are the focus here) are annual company documents mainly addressed to shareholders but also to other organizational stakeholders. Thus, we expect that firm size will also positively affect dedicated attention to shareholders.

Hypothesis 1. Firm size has a positive relationship with attention to shareholders.

RDT suggests that the use of organizational slack as a strategy may help organizations cope with interdependence because it provides them with leeway to deal with a larger set of environmental elements. From an ABV standpoint, organizational slack enables an expansion of the attention capacity because it represents extra resources available to the organization that can be used to increase organizational attention to external and internal constituents. Therefore, from both RDT and the ABV points of view, organizational slack provides organizations with resources that can be used to better manage their external environment.

However, whereas RDT provides a deterministic effect suggesting that dependency on external resources pressures firms to allocate attention to its various stakeholders, ABV provides a more contingent outcome. According to RDT, organizations operating in similar environments will face some similar constraints resulting in some degree of homogeneity in their outcomes (Drees \& Heugens, 2013). An $A B V$ view adds variance on organizational outcomes because it argues that attention processes at organizational level account for particular and discrete effects. Therefore, from a purely RDT 
perspective, public-listed firms are dependent on financial capital and, consequently, they will attend to shareholders. Given our methodological choice to approach organizational attention centering on one specific governance channel (Ocasio, 1997), we expect these extra resources will be directed to attend to other stakeholders. Thus, from an ABV perspective, we anticipate a negative relationship between organizational slack and attention to shareholders.

Hypothesis 2a. Firm slack has a positive relationship with attention to shareholders.

Hypothesis 2b. Firm slack has a negative relationship with attention to shareholders.

From a resource dependence perspective, measures of performance are proxies for two distinct concepts, namely effectiveness and efficiency. According to Pfeffer and Salancik (1978), the difference between these concepts "is at the heart of the external versus internal perspective on organizations" (p. 11). On one hand, effectiveness, an external standard, is the ability of an organization to create acceptable actions and outcomes. On the other hand, efficiency, an internal standard, is the ability of an organization to make good use of resources in relation to the output. Since we are interested in understanding firms' attention to shareholders, a specific constituency, primary stakeholder and resource provider, we use financial market performance as a proxy measurement of the firm's effectiveness towards its shareholders who are mostly interested in the extent to which focal firms increase their overall market value (Drees \& Heugens, 2013). Conversely, accounting measures of financial performance such as return on equity (ROE) or return on assets (ROA) are ratios of utilization of resources to output, and can therefore be seen as proxies for a firm's efficiency. However, market value is the ultimate demand of shareholders as a stakeholder group (Sundaram \& Inkpen, 2004).

Therefore, we propose that firm performance has different effects on attention to shareholders depending on the measures used. Whereas accounting measures of firm performance are good proxies for the efficient use of internal resources, market measures are better proxies for the effectiveness in meeting shareholder demands. Thus, based on the assumptions of RDT, we hypothesize that market financial performance affects attention to shareholders, whereas accounting financial performance has no effect.

Hypothesis 3. Firm accounting performance has no effect on attention to shareholders.

Hypothesis 4. Firm market performance has a negative relationship with attention to shareholders.

\section{Hypothesis: country level effects}

In the literature on corporate governance, researchers make a broad distinction between two governance systems: outside and insider systems. Outsider systems (referred to as the Anglo-American shareholder model) are characterized by dispersed ownership of firms and are systems in which markets for corporate control work as a crucial mechanism tackling agency problems between managers and shareholders. Conversely, insider systems (referred to as the stakeholder model in Continental European countries) are characterized by concentrated ownership and represent systems in which large shareholders play an important role in monitoring management (Aguilera \& Jackson, 2003). Thus, the relationship between firms and their shareholders is expected to differ between these highly stylized governance systems (Aguilera, Filatotchev, Gospel, \& Jackson, 2008).

We argue that organizational attention and outcomes are not context-free and, thus, "different organizational environments mediate hypothesized relationships between sets of practices and organizational outcomes, such as effectiveness, efficiency, or performance" (Aguilera et al., 2008, p. 478). An important implication of the contextual effects of the environment on organizations relates to the various ways in which firms operating in different countries relate to their stakeholders. "Comparative research in CSR between Europe and the United States has identified remarkable differences between companies on each side of the Atlantic" (Matten \& Moon, 2008, p. 404). In European countries, the role of stakeholders is more prominent than in the U.S., where the notion of 
shareholder supremacy prevails. The role of capital markets as a source of finance (Aguilera \& Jackson, 2003) and the influence of shareholders on decision-making and managerial discretion (Crossland \& Hambrick, 2007) provide explanations for the question of why corporations in the U.S. are explicit about their CSR policies and practices whereas in Europe they tend to be more implicit (Matten \& Moon, 2008).

Both North-American and European firms will use explicit language to explain poor performance to their shareholders. However, given shareholder supremacy in the American context and the focus on stakeholders in the European context, we expect variation between these contexts. Therefore, we hypothesize that the relationship between firm performance and shareholder attention will be comparatively higher for American companies.

Hypothesis 5. The relationship between market performance and attention to shareholders is stronger for American companies than for European companies.

\section{Data and Methods}

In our study, we follow a number of empirical research projects that have measured attention using content analysis of letters to shareholders (Cho \& Hambrick, 2006; Levy, 2005; Yadav et al., 2007). We believe this communication channel has potential to test the environmental and organizational effects on organizational attention and is consonant with both RDT and ABV research. Firstly, we agree with Rindova, Becerra and Contardo's (2004) proposition that those documents and texts are important means for acquiring stakeholder support, which can contribute to organizational outcomes. Secondly, the use of annual reports and letters to shareholders enables comparison across firms and across different contextual environments. Thirdly, annual reports are directed to general external and internal audiences, providing different types of information, from financial results to HR policies.

Within the annual reports, letters to shareholders offer a qualitative view of the quantitative information presented. More specifically, letters to shareholders must contain an accurate account of the year under analysis and also communicate "commitment to enhancing shareholder wealth" (Segars \& Kohut, 2001, p. 537). Hence, these letters are good proxies of firms' attention because they represent a relatively homogeneous communication channel that is under the purview of the top management team, who will at least revise the content of this communication to ensure its validity. They serve as "particularly good indicators of the major topics that organizational managers attend to" and reveal "how much attention is paid to various aspects of the environment, relative to others" (D'Aveni \& MacMillan, 1990, p. 640).

Although annual reports, in general, and letters to shareholders specifically, can be seen as eligible communication channels to manage external impressions about organizations (Abrahamson \& Park, 1994; Staw et al., 1983) they are also relevant governance channels which reflect important concrete and contextual aspects of the organization's attention process (Ocasio \& Joseph, 2005, 2006). Thus, we chose to use letters to shareholders to collect data about organizational attention not only because they provide comparable measures of attention, which are publicly available, but, more importantly, because of their central role in the model of situated attention. When taken together, these characteristics make shareholder's letters a suitable data source for our research objectives.

\section{Sample}

Our sample derives from the list adopted by the Reputation Institute. The Reputation Institute is responsible for the RepTrak dataset, an index of corporate reputation scores, created on the basis of the result of a survey conducted in different countries during the first two of months of every calendar year (Reputation Institute, 2007). The sampling process adopted by the Reputation Institute starts from the list of the world's 300 largest companies (in terms of revenue). Their original sample is as large as 1000 
companies, however only 600 companies are actually rated. Companies included in the RepTrak survey are only rated in their home countries and must have sufficient general public visibility to be included.

In our research we started from the list of 600 companies from 24 different countries rated by the RepTrak survey in 2006. From this list, we excluded privately held firms and focused on 410 publicly listed companies for which the financial data was publicly available. We also excluded a number of companies from the list of 410 publicly listed companies either because they were holding companies (13) or because we could not analyze their letters to shareholders (84). Of these cases, some companies did not publish letters to shareholders in their annual reports, others did not even have an annual report available (only their financial statements), some companies' letters to shareholders were only published in the native language of the home country and finally some letters could not be digitally converted to be used in the qualitative analysis software (NVivo 2.0). Despite the reduction of the number of firms, the sample includes firms from all 24 countries of the initial list. Our final sample is, therefore, comprised of 313 letters to shareholders published in 2004.

\section{Coding procedure}

The use of content analysis of letters to shareholders to study and measure attention has been successfully applied in past research (Cho \& Hambrick, 2006; Levy, 2005; Yadav et al., 2007). The basic idea behind this technique is to classify text into reliable content categories, which are then converted into valid variables for use in further research. In our research we used phrases or sentences as our unit of analysis based on the assumption that "groups of words reveal underlying themes" (Duriau, Reger, \& Pfarrer, 2007, p. 6).

The coding procedure had several stages. In the first phase, the authors read 10 letters to shareholders of companies from three different home-countries (US, The Netherlands and Brazil) to check whether there were qualitative differences in the content regarding shareholder attention and other stakeholder attention. We understand shareholder attention as the time and effort allocated by the firm to meet the interests of its shareholders. Thus, strategic actions such as mergers and acquisitions, issues concerning buyouts, dividends and IPOs, activism and financial information disclosure are some of the issues we classify as firm attention to their shareholders. On the other hand, we classify local communities' support, charity, corporate environmental programs, customer satisfaction, procurement, organizational health and safety as firm attention to stakeholders regardless of its specific group. Although attending to the demands of different constituencies (society at large, customers, suppliers, employees, and so on), these are topics known to be stakeholder oriented (Donaldson \& Preston, 1995).

In a second stage, the topics that appeared in the letters to shareholders were discussed with two scholars with expertise in the fields of corporate governance and stakeholder management. By comparing these topics with the literature, the objective of these discussions was to develop an inventory of unambiguous topics that could be found on letters to shareholders that would indicate shareholder and/or stakeholder attention. After a series of discussions and after sending the list of grouped categories to an expert panel consisting of 10 scholars from the field of management studies, we entered a third phase. We conducted a test run of our coding scheme using NVivo software, assigning eight letters to shareholders to a Master's student for analysis. The author simultaneously coded the same letters. Possible inconsistencies and ambiguities were discussed before the remaining letters were coded. This process aimed at having a consistent set of coding categories and guidelines to help solve possible issues related to ambiguous and/or complex texts. The final version of the coding scheme is comprised by a list of 22 categories grouped according to focus of attention (this list is available from the authors). All remaining letters were coded by the author.

\section{Dependent variable: organizational attention}

Attention was measured using the results of the content analyzed letters. The proxies for shareholder and stakeholder attention were operationalized following the measures of attention used in previous works such as D'Aveni and MacMillan (1990) (degree of attention) and Levy (2005) 
(proportionate attention). We created a proxy measure for attention to shareholders, shareholder attention that is the ratio of characters coded under themes (or categories) of shareholders interests divided by the total number of characters displayed on the letter. Similarly, stakeholder attention is the number of characters coded under stakeholder categories divided by absolute attention.

\section{Independent variables and controls}

There are several measures that could be used to indicate size, including total assets, total sales and number of employees. We opted to use total assets instead of total sales and the number of employees, which could also be seen as proxies for customers and employees dependence, respectively. Among measures of organizational slack (Bourgeois, 1981), we used the current ratio (ratio of current assets to current liabilities), which is a measure of organizational slack that indicates the firm's ability to meet immediate obligations or debts.

We used return on equity (ROE) and Tobin's Q for our measures of financial performance; accounting and market, respectively. Whereas ROE captures how well the firm is using its resources, Tobin's Q measures investors' expectations of a firm's profitability. We calculated Tobin's Q as the ratio of the firm's market value to its replacement costs using the formula put forth by Lindenberg and Ross (1981). All of these data were drawn from the Worldscope database.

To test the differences in strength of the relationship between attention to shareholders and market financial performance, we created categorical variables according to the country of origin of the firms in the sample. The 24 different countries were categorized in 3 different groups: U.S. (76 companies), European Union (Denmark, Finland, France, Germany, Italy, Netherlands, Norway, Poland, Spain, Sweden, Switzerland and UK; 126 companies) companies and all other countries were categorized as Rest of the World (Australia, Brazil, Canada, Chile, China, India, Japan, Mexico, Russia, South Africa, South Korea; 111 companies).

The model of situated attention and firm behavior (Ocasio, 1997) highlights the crucial role that decision-makers play in directing organizational attention because of their influence on the valuation of issues, especially in governance channels. The ABV distinguishes between players and decision-makers. Accordingly, decision-makers are social actors that participate in procedural and communication channels and players are social actors (or a group of actors) that can influence the attention process by exercising their power.

Assuming that the board of directors is a concrete group of actors that have some control or influence over the CEO, we added variables indicating board independence to control for the influence of directors (players) on the CEO (decision-maker). We used a dichotomous measure to indicate that a CEO has a dual role as chair of the board of directors (CEO duality), and the ratio of inside directors, or the number of members of the board who are also part of the management team divided by the total number of directors on the board (see Dalton, Daily, Ellstrand, \& Johnson, 1998). These two variables provide proxy measures indicating higher CEO discretion over the content of the letters to shareholders.

\section{Analysis and model development}

In order to test our hypotheses, we developed two sets of models for the different dependent variables: shareholder attention and stakeholder attention. As discussed earlier, our measures of attention were collected by means of content analysis of the text of one specific communication and procedural channel in the model of situated attention and firm behavior (i.e. letters to shareholders). Hence, despite the different dependent variables, our sets of models include the same independent variables that were used to test the antecedents of attention to shareholders who are the main target audience of the content analyzed documents. We test whether the antecedents of shareholder attention also have an effect on stakeholder attention. In these set of models we investigate whether or not (positive) financial performance offers decision-makers more flexibility in terms of the attention they 
focus on shareholders and whether or not this shareholder attention slack is dedicated to other corporate constituencies.

Our two dependent variables have mean values that are significantly different from zero (Table 1 provides a summary of mean and standard deviation values), very few cases have values that equal zero and the frequency distributions tend toward normality. Additionally, dependent and independent variables are independent and the final sample is free of outliers. Thus, we could adopt ordinary least squares (OLS) regression analysis which is a simple and straightforward statistical technique that provides parsimonious and unbiased estimates (Berry, 1993). OLS has the additional advantage of providing an intuitive means of testing moderating effects, such as those hypotheses regarding country effects on shareholder attention (Cohen, Cohen, West, \& Aiken, 2003). The inclusion of interaction terms may contribute to multicollinearity (a linear relationship between two or more independent variables), which, in turn, may artificially inflate the size of the regression coefficients (Aiken \& West, 1991; Berry, 1993). For that reason, we used mean-centered continuous measures for the variable included in the interaction terms (i.e. market financial performance). According to the results of the multicollinearity diagnostic tests we carried out, our models do not reveal multicollinearity problems (none of the computed variance inflation factors (VIF) were higher than five). Due in part to the increased variance of our sample that consists of data on companies from various countries, and also to the number of cases with missing values for one or more of the independent variables, we conducted a post hoc power analysis (Cohen, 1992) of our results to test the effect size of our statistical model. This test revealed that all our relevant models exhibited more than $80 \%$ power (specifically, the full model for shareholder attention exhibited $92.49 \%$ power and the full model for stakeholder attention exhibited $80.92 \%$ power).

\section{Results}

Table 1 provides descriptive statistics and bivariate correlation coefficients for all of the variables included. The results presented in Table 2 provide support for four out of five of our hypotheses regarding shareholder attention. On the one hand, the coefficients for size regressed on shareholder attention are not significant. On the other hand, the coefficients for slack are found to be statistically significant (yet at $10 \%$ level of significance) and negative in all relevant models for attention to shareholders, providing confirmatory evidence for Hypothesis $2 \mathrm{~b}$. Both hypotheses regarding the effects of financial performance were confirmed. Coefficients for accounting measures of financial performance were not found to be significant (Hypothesis 3) and, as such, have no effect on shareholder attention. Conversely, coefficients for the effects of market financial performance on shareholder attention are significant and negative (Hypothesis 4).

Finally, our country level hypothesis was also confirmed by the coefficients of the interaction terms between European companies (and companies from the rest of the world) and market financial performance. For a better grasp of the interaction effects between country groups and financial market performance, we calculated the slope coefficients for the European companies and also for companies in the rest of the world and plotted the relationships between the country groups' dummy variables at the levels of bad and good financial performance (i.e. one standard deviation below and above the mean) (Aiken \& West, 1991). As depicted by Figure 1, we can see that shareholder attention in American companies is considerably more sensitive to variation in financial market performance, than it is in companies from other countries. 


\section{Table 1}

\section{Means, Standard Deviations and Correlations}

\begin{tabular}{|c|c|c|c|c|c|c|c|c|c|c|c|c|c|}
\hline & $\mathrm{N}$ & Mean & s.d. & 1 & 2 & 3 & 4 & 5 & 6 & 7 & 8 & 9 & 10 \\
\hline 1. Shareholder attention & 313 & 28.78 & 17.61 & & & & & & & & & & \\
\hline 2. Stakeholder attention & 313 & 16.00 & 12.89 & $-.44 * * *$ & & & & & & & & & \\
\hline 3. CEO duplicity ${ }^{\mathrm{a}}$ & 309 & 0.33 & 0.47 & 0.02 & 0.01 & & & & & & & & \\
\hline 4. Ratio inside directors & 291 & 0.18 & 0.20 & 0.09 & -0.03 & 0.04 & & & & & & & \\
\hline 5. Size & 313 & 4.48 & 0.72 & -0.03 & 0.09 & 0.10 & 0.02 & & & & & & \\
\hline 6. Slack & 243 & 0.09 & 0.20 & $-.14 * *$ & 0.11 & -0.04 & $-.18 * * *$ & $-.19 * * *$ & & & & & \\
\hline 7. Accounting performance & 299 & 1.16 & 0.35 & 0.01 & 0.07 & 0.02 & $-.12 * *$ & -0.01 & 0.07 & & & & \\
\hline 8. Market performance & 238 & 1.15 & 0.73 & -0.09 & 0.05 & $.15^{* *}$ & -0.06 & -0.11 & 0.11 & $.33 * * *$ & & & \\
\hline 9. Reputation score & 313 & 64.35 & 9.19 & -0.05 & 0.01 & 0.03 & 0.04 & $-.22 * * *$ & $.17 * * *$ & -0.04 & $.13 * *$ & & \\
\hline 10. European companies ${ }^{\mathrm{a}}$ & 126 & 0.40 & 0.49 & $.14 * *$ & $-.13 * *$ & $-.29 * * *$ & $-.21 * * *$ & -0.08 & -0.02 & 0.03 & 0.01 & 0.00 & \\
\hline 11. ROW companies ${ }^{\mathrm{a}, \mathrm{b}}$ & 111 & 0.35 & 0.48 & -0.03 & 0.09 & $-.21 * * *$ & $.35 * * *$ & $-.16 * * *$ & -0.05 & -0.09 & $-.23 * * *$ & -0.01 & $-.61 * * *$ \\
\hline
\end{tabular}

Note. ${ }^{a}$ Dummy variable. ${ }^{\mathrm{b}}$ ROW stands for Rest of the World

$* \mathrm{p}<0.1, * * \mathrm{p}<0.05, * * * \mathrm{p}<0.01$. 
Table 2

\section{Results of OLS Regression Analysis of Shareholder Attention ${ }^{\text {a }}$}

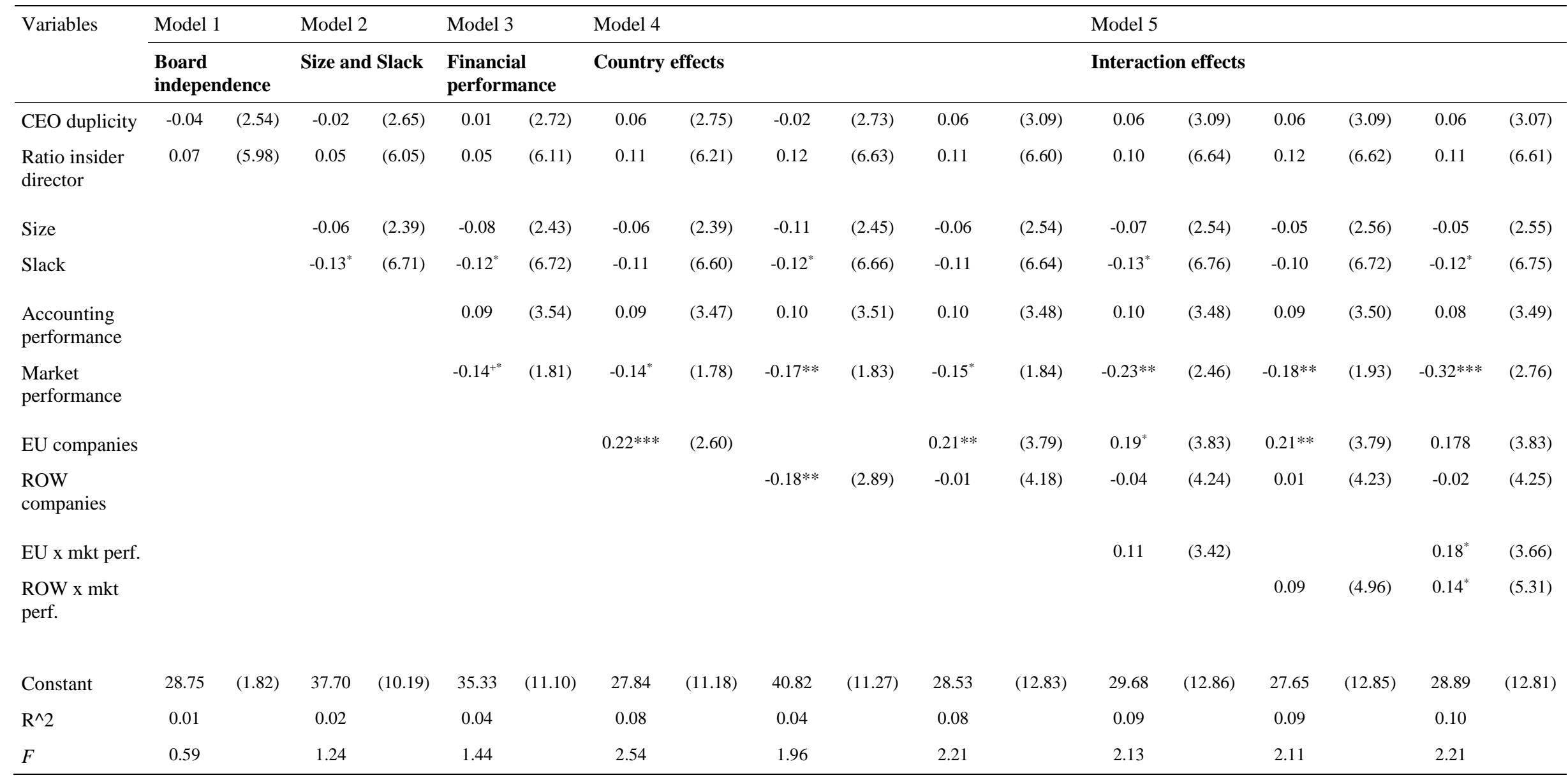

Note. ${ }^{a}$ Standard errors are in parenthesis. $\mathrm{N}=207$.

$* \mathrm{p}<0.1, * * \mathrm{p}<0.05, * * * \mathrm{p}<0.01$. 

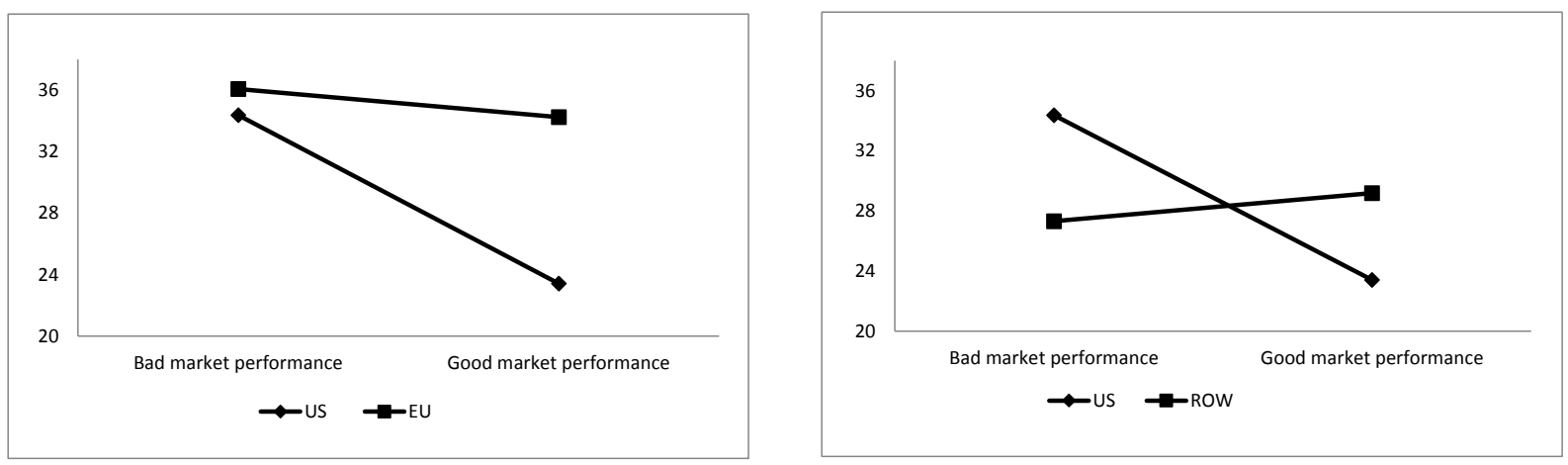

Figure 1. Moderating Effects of Country Groups on Shareholder Attention

In sum, we found support for the all hypotheses with the exception of Hypothesis 1, which predicted a positive relationship between organizational size and attention to shareholders. Our findings suggest that attention to shareholders is sensitive (and negatively related) to slack (Hypothesis 2) and market performance (Hypothesis 4). Our concurrent test of the effects of slack on attention to shareholders indicates that $\mathrm{ABV}$ might be helpful to explain the contingent effects of environmental factors on organizational attention (noting its level of significance). Additionally, we found support for the non-effect of accounting performance on attention to shareholders, as was predicted by Hypothesis 3. Finally, our results support our hypothesized country-level effects (Hypothesis 5) suggesting that attention to shareholders in American companies is more sensitive to market performance when compared to attention to shareholders in European companies.

\section{Additional analysis}

\section{Does good financial performance have a positive effect on stakeholder attention?}

Although addressed to shareholders, the letters to shareholders are also of interest to other constituents of the firm. In some cases the opening of the letter explicitly addresses stakeholders and very often all letters include some paragraphs discussing employee interests and demands. Therefore, we also tested whether or not financial performance and other antecedents of shareholder attention also affect stakeholder attention. When experiencing positive financial performance and in the presence of organizational slack, attention to shareholders was negatively affected. Does strong financial performance offer managerial flexibility to address stakeholders' interests, thereby increasing relative stakeholder attention? The results presented in Table 3 indicate that stakeholder attention is neither affected by the firm's market financial performance nor by organizational slack, as their coefficients were not found to be significant. However, the coefficient of size is positive and significant, indicating that larger firms pay more attention to their stakeholders. 


\section{Table 3}

\section{Results of OLS Regression Analysis of Stakeholder Attention ${ }^{\text {a }}$}

\begin{tabular}{|c|c|c|c|c|c|c|c|c|c|c|c|c|c|c|c|c|c|c|}
\hline \multirow{3}{*}{$\begin{array}{l}\text { Variables } \\
\text { CEO duplicity }\end{array}$} & \multirow{2}{*}{\multicolumn{2}{|c|}{$\begin{array}{l}\text { Model } 1 \\
\text { Board } \\
\text { independence }\end{array}$}} & \multirow{2}{*}{\multicolumn{2}{|c|}{$\begin{array}{l}\text { Model } 2 \\
\text { Size and } \\
\text { Slack }\end{array}$}} & \multirow{2}{*}{\multicolumn{2}{|c|}{$\begin{array}{l}\text { Model } 3 \\
\text { Financial } \\
\text { performance }\end{array}$}} & \multirow{2}{*}{\multicolumn{2}{|c|}{$\begin{array}{l}\text { Model } 4 \\
\text { Country effects }\end{array}$}} & \multicolumn{10}{|c|}{ Model 5} \\
\hline & & & & & & & & & \multicolumn{10}{|c|}{ Interaction effects } \\
\hline & 0.00 & $(1.87)$ & -0.05 & $(1.94)$ & -0.07 & $(2.00)$ & -0.12 & (2.04) & -0.03 & $(2.00)$ & -0.06 & $(2.28)$ & -0.06 & $(2.28)$ & -0.06 & $(2.28)$ & -0.06 & $(2.28)$ \\
\hline $\begin{array}{l}\text { Ratio insider } \\
\text { directors }\end{array}$ & -0.04 & $(4.40)$ & -0.02 & $(4.40)$ & -0.02 & $(4.50)$ & -0.07 & $(4.60)$ & -0.11 & $(4.85)$ & -0.10 & $(4.87)$ & -0.11 & $(4.90)$ & -0.11 & $(4.89)$ & -0.11 & $(4.91)$ \\
\hline Size & & & $0.16 * *$ & $(1.75)$ & $0.17 * *$ & $(1.79)$ & $0.16^{* *}$ & (1.77) & $0.21 * * *$ & $(1.79)$ & $0.19 * *$ & $(1.88)$ & $0.19 * *$ & $(1.88)$ & $0.19 * *$ & (1.89) & $0.19 * *$ & $(1.89)$ \\
\hline Slack & & & 0.08 & $(4.92)$ & 0.07 & $(4.65)$ & 0.06 & (4.89) & 0.07 & $(4.87)$ & 0.07 & $(4.89)$ & 0.06 & $(4.99)$ & 0.06 & $(4.96)$ & 0.05 & $(5.02)$ \\
\hline $\begin{array}{l}\text { Accounting } \\
\text { performance }\end{array}$ & & & & & -0.02 & $(2.60)$ & -0.02 & $(2.57)$ & -0.03 & $(2.56)$ & -0.03 & $(2.57)$ & -0.03 & $(2.57)$ & -0.02 & $(2.59)$ & -0.02 & $(2.59)$ \\
\hline $\begin{array}{l}\text { Market } \\
\text { performance }\end{array}$ & & & & & 0.09 & (1.33) & 0.09 & $(1.32)$ & $0.13 * *$ & $(1.34)$ & 0.12 & $(1.35)$ & 0.06 & $(1.81)$ & $0.15^{*}$ & $(1.43)$ & 0.10 & $(2.05)$ \\
\hline EU companies & & & & & & & $-0.19 * *$ & (1.93) & & & -0.08 & $(2.80)$ & -0.09 & $(2.83)$ & -0.08 & $(2.80)$ & -0.09 & $(2.84)$ \\
\hline ROW companies & & & & & & & & & $0.22 * *$ & $(2.12)$ & 0.16 & $(3.08)$ & 0.15 & (3.13) & 0.14 & $(3.12)$ & 0.14 & $(3.15)$ \\
\hline EU x mkt perf. & & & & & & & & & & & & & 0.08 & $(2.53)$ & & & 0.05 & $(2.72)$ \\
\hline ROW x mkt perf. & & & & & & & & & & & & & & & -0.08 & $(3.66)$ & -0.06 & (3.94) \\
\hline Constant & 16.58 & $(1.34)$ & 0.45 & $(7.46)$ & -0.18 & $(8.17)$ & 4.49 & $(8.28)$ & -5.24 & $(8.24)$ & -1.95 & $(9.46)$ & -1.36 & $(9.50)$ & -1.39 & $(9.48)$ & -1.12 & $(9.52)$ \\
\hline $\mathrm{R}^{\wedge} 2$ & 0.01 & & 0.03 & & 0.03 & & 0.06 & & 0.06 & & 0.07 & & 0.08 & & 0.08 & & 0.08 & \\
\hline$F$ & 0.13 & & 1.39 & & 1.14 & & 1.90 & & 2.12 & & 1.91 & & 1.77 & & 1.80 & & 1.64 & \\
\hline
\end{tabular}

Note. ${ }^{a}$ Standard errors are in parenthesis. $\mathrm{N}=207$.

$* \mathrm{p}<0.1, * * \mathrm{p}<0.05, * * * \mathrm{p}<0.01$. 


\section{Do letters to shareholders actually reflect impression management efforts rather than organizational attention?}

Despite being a suitable data source for the current study, there are concerns regarding a possible use of these of letters to shareholders for impression management purposes. Impression management literature suggests that corporate communications reflect intended strategies to persuade and convince the external public about the appropriateness of organizational actions. It further suggests that attempts to manage impressions are particularly prominent in performance justifications (Abrahamson \& Park, 1994; Staw et al., 1983). Impression management scholars would argue that letters to shareholders are carefully crafted documents intended to manipulate external audiences' perceptions rather than governance and procedural channel reflecting organizational attention, as is suggested by the ABV literature.

To test whether or not texts derived from letters to shareholders that are dedicated either to shareholders or stakeholders simply reflect impression management efforts rather than organizational attention, we estimate the effects of our basic model, including board independence measures, companylevel variables (size, slack and financial performance) and our measures of shareholder and stakeholder attention against the reputation scores measured by the RepTrak data. Results of the regression analysis of corporate reputation reduce the likelihood that impression management as an alternative explanation is the correct explanation and corroborate our argument in favor of organizational attention. According to the results presented in Table 4, neither shareholder nor stakeholder attention has a significant effect on corporate reputation. 
Table 4

Results of OLS Regression Analysis of Corporate Reputation ${ }^{\text {a }}$

\begin{tabular}{|c|c|c|c|c|c|c|c|c|c|c|c|c|}
\hline \multirow{3}{*}{$\begin{array}{l}\text { Variables } \\
\text { CEO duplicity }\end{array}$} & \multirow{2}{*}{\multicolumn{3}{|c|}{$\begin{array}{l}\text { Model } 1 \\
\text { Board independence }\end{array}$}} & \multirow{2}{*}{\multicolumn{3}{|c|}{$\begin{array}{l}\text { Model } 2 \\
\text { Size and Slack }\end{array}$}} & \multirow{2}{*}{\multicolumn{3}{|c|}{$\begin{array}{l}\text { Model } 3 \\
\text { Financial performance }\end{array}$}} & \multirow{2}{*}{\multicolumn{3}{|c|}{$\begin{array}{l}\text { Model } 4 \\
\text { Relative attention }\end{array}$}} \\
\hline & & & & & & & & & & & & \\
\hline & -0.07 & $(1.28)$ & -0.03 & $(1.30)$ & -0.07 & $(1.33)$ & -0.07 & $(1.33)$ & -0.07 & (1.33) & -0.07 & $(1.33)$ \\
\hline Ratio insider directors & 0.08 & $(3.02)$ & $0.12^{*}$ & $(2.97)$ & 0.11 & (2.99) & 0.11 & $(3.00)$ & 0.11 & (2.99) & 0.11 & $(2.99)$ \\
\hline Size & & & -0.11 & (1.18) & -0.1 & (1.19) & -0.09 & $(1.19)$ & -0.07 & $(1.20)$ & -0.08 & $(1.20)$ \\
\hline Slack & & & $0.23 * * *$ & (3.29) & $0.22 * * *$ & $(3.28)$ & $0.22 * * *$ & $(3.31)$ & $0.22 * * *$ & $(3.29)$ & $0.22 * * *$ & $(3.31)$ \\
\hline Accounting performance & & & & & -0.09 & $(1.73)$ & -0.09 & $(1.74)$ & -0.09 & $(1.73)$ & -0.09 & $(1.74)$ \\
\hline Market performance & & & & & $0.16^{* *}$ & $(0.88)$ & $0.16 * *$ & $(0.89)$ & $0.17 * *$ & $(0.89)$ & $0.16^{* *}$ & $(0.89)$ \\
\hline Shareholder attention & & & & & & & -0.03 & $(0.04)$ & & & -0.06 & $(0.04)$ \\
\hline Stakeholder attention & & & & & & & & & -0.06 & $(0.05)$ & -0.08 & $(0.05)$ \\
\hline Constant & 65.84 & $(0.92)$ & 72.24 & $(5.00)$ & 73.30 & $(5.42)$ & 73.79 & $(5.57)$ & 73.21 & $(5.43)$ & 74.38 & $(5.59)$ \\
\hline $\mathrm{R}^{\wedge} 2$ & 0.01 & & 0.08 & & 0.10 & & 0.10 & & 0.11 & & 0.11 & \\
\hline$F$ & 1.09 & & 4.36 & & 3.83 & & 3.29 & & 3.38 & & 3.04 & \\
\hline
\end{tabular}

Note. ${ }^{a}$ Standard errors are in parenthesis. $\mathrm{N}=223$.

$* p<0.1, * * p<0.05, * * * p<0.01$ 


\section{Discussion}

An interesting observation drawn from our results relate to the effect of organizational size on shareholder and stakeholder attention. In accordance with RDT, larger firms are more dependent on external resources due to its complexity (Drees \& Heugens, 2013; Pfeffer \& Salancik, 1978). Therefore, larger firms are more likely to pay attention to a diverse set of capital providers or stakeholders. According to our results, size affects allocation of attention. Although we didn't find effects on attention to shareholders, our findings are consistent with RDT because we observed effects of organizational size on attention to other stakeholders than shareholders. Whereas this difference of the effect of size can be explained by the RDT and the effectiveness argument, the effects of slack on allocation of attention are better explained by ABV. Slack has a negative effect on allocation of attention towards shareholders. We expected this negative relationship between organizational slack and attention to shareholders. Yet, from a RDT perspective, organizational slack would provide focal firms with extra room to deal with other external interdependencies. Following resource dependence explanation, one expects that this spare capacity would be directed towards other stakeholders. This is not that case considering that organizational slack has no significant effect on attention to stakeholders.

In addition to the effects of size on organizational attention, our results pertaining to organizational slack and performance also provide insights. The negative effects of organizational slack and market firm performance on attention to shareholders indicate that these two firm level characteristics CEOs some leeway in terms of their ability to dedicate less attention to shareholders. However, a company's strong financial position and the latitude it provides to the CEO, does not necessarily guarantee that more attention will be allocated to other stakeholders. Although our results are not incompatible with the idea that more managerial discretion has an effect on shareholder attention, they do not substantiate the subsequent suggestion that an increase in managerial discretion, due to decreased shareholder pressure, leads to the attribution of increased attention to other stakeholders.

Our further analysis of the effects of financial market performance on shareholder attention in different countries may offer a better explanation for other studies on attention that rely on data derived from content analyzed letters to shareholders of companies from a single country, that is the U.S. (Cho \& Hambrick, 2006; Levy, 2005; Yadav et al., 2007). The prevalence of a shareholder primacy logic in the U.S. not only explains the sensitivity of attention to shareholders to variances in financial market performance. Additionally, it offers an explanation of the subsequent re-focusing of attention to other stakeholders and other issues of interest to the CEO.

These results, together with the results relating to the effects of organizational size and slack, are better substantiated if we consider the ABV (and not only RDT explanations). In the very specific case of letters to shareholders, one among many governance channels (Ocasio, 1997), good market performance might offer CEOs more freedom to attend to other stakeholders, but also to reinforce the company's identity. In some of the letters to shareholders signed by Walt Disney former CEO, Michael D. Eisner, one is easily captivated by his description of the delightful and entertaining ambience of a Thanksgiving dinner:

I'm writing this letter on Thanksgiving day in Vermont with my family while waiting for Kermit to float by on television at the Macy's parade, waiting for the arrival of my children who are driving up to New England, and waiting for our turkey meal with the smell of chestnuts interrupting my thoughts. (The Walt Disney Company, 2004).

From an $\mathrm{ABV}$ standpoint, letters to shareholders are also important communication channels where CEOs' can express their own ideas and views of the world. As an informative illustration, take the popular and much anticipated letters to shareholders written by Warren Buffet:

As the year progressed, a series of life-threatening problems within many of the world's great financial institutions was unveiled. This led to a dysfunctional credit market that in important respects soon turned non-functional. The watchword throughout the country became the creed I 
saw on restaurant walls when I was young: "In God we trust; all others pay cash". (Berkshire Hathaway Inc., 2009).

Finally, according to ABV, letters to shareholders are governance channels that affect the situation where decision-makers find themselves and also their focus of attention. Hence, these letters also provide CEO's with space to explain contingencies. An illustration from the coded letters comes from Swedish companies. According to the statistics of the Indian Ocean tsunami that happened in the end of 2004, Sweden suffered the highest losses for any country outside of Asia. The tragedy affected the Swedes in general, and impacted firms as well:

The last few days of the year were darkened by the disaster in south-east Asia. Many customers and employees are closely and tragically affected. One of Handelsbanken's principles is not to donate money to charity. While our balance sheet may look large, not one single krona is our own. The money belongs to the people that make deposits and to our shareholders. Being generous with other people's money is a cheap way of earning reputation of magnanimity. This is not something we usually do and it does not comply with our fundamental values. But there are disasters which are so enormous that rational arguments must fall silent. (Svenska Handelsbank, 2004).

\section{Conclusion}

Starting from the central tenet of the ABV that "to explain firm behavior is to explain how firms distribute and regulate attention of their decision-makers" (Ocasio, 1997, p. 188), we suggest that the attentional perspective (Ocasio, 1995, 1997) of firm behavior is a more comprehensive model of the linkage between environment and organization as it takes both external and internal aspects of the environment into consideration. Because the $\mathrm{ABV}$ deals with multiple processes affecting firm behavior at environmental, organizational and individual levels, it not only offers a less deterministic view of the influence of the environment on focal organizations, but it also incorporates the managerial role as providing an additional explanation of organizational responses.

Our sample consists of firm-level data from companies from 24 different countries, bringing additional variance to the research design. As we argued, there are many components of the organizational environment, including those at the country level, that might further our understanding of firm-level phenomena (Crossland \& Hambrick, 2007). As a result of adding country-level variance to our analysis, we experienced additional difficulties in identifying the very specific contextual factors that explain more of the phenomena under investigation. Following Aguilera and Jackson (2003) and Matten and Moon (2008), there is a wide set of elements pertaining to organizations' environments at the country level that affects how organizations respond to their stakeholders. It is not only the variety of these elements that adds to their complexity, but also the different combinations of these contextual elements and interactions between environmental and organizational characteristics that are also required for a full explanation of organizational practices, corporate strategies, and firm behavior. When we proposed testing country-level effects in our explanation of organizational attention, we were aware of the increased variance and complexity that was necessarily added to the current research problem as a result. With this in mind, we sought to extend beyond explaining variance alone in order to seek more statistical power and significant effects. In doing so, we geared our analysis toward capturing our arguments about the influence of the environment on very specific and localized aspects of organizational attention.

Our theoretical arguments and subsequent tests of our hypotheses highlight the complementary nature of the resource dependence theory and the attention-based view of the firm. The ABV provides RDT with a more comprehensive view of the relationship between environment and organizational outcomes, including both the external and the internal constraints on organizations. RDT, in turn, 
complements $\mathrm{ABV}$ by making the effects of the environment on attention structures and, ultimately, on organizational behavior, more explicit.

\section{References}

Abrahamson, E., \& Hambrick, D. C. (1997). Attentional homogeneity in industries: the effect of discretion. Journal of Organizational Behavior, 18(S1), 513-532. doi: 10.1002/(sici)10991379(199711)18:1+<513::aid-job905>3.3.co;2-\#

Abrahamson, E., \& Park, C. (1994). Concealment of negative organizational outcomes: an agency theory perspective. Academy of Management Journal, 37(5), 1302-1334. doi: 10.2307/256674

Aguilera, R. V., \& Jackson, G. (2003). The cross-national diversity of corporate governance: dimensions and determinants. Academy of Management Review, 28(3), 447-465. doi: 10.5465/AMR.2003.10196772

Aguilera, R. V., Filatotchev, I., Gospel, H., \& Jackson, G. (2008). An organizational approach to comparative corporate governance: costs, contingencies, and complementarities. Organization Science, 19(3), 475-492. doi: 10.1287/orsc.1070.0322

Aiken, L. S., \& West, S. G. (1991). Multiple regression: testing and interpreting regressions. London: Sage Publications.

Barnett, M. L. (2008). An attention-based view of real options reasoning. Academy of Management Review, 33(3), 606-628. doi: 10.5465/AMR.2008.32465698

Berkshire Hathaway Inc. (2009). 2008 annual report. Retrieved from http://www.berkshirehathaway.com/2008ar/2008ar.pdf

Berry, W. D. (1993). Understanding regression assumptions. London: Sage Publications.

Bourgeois, L. J., III (1981). On the measurement of organizational slack. Academy of Management Review, 6(1), 29-39. doi: 10.5465/AMR.1981.4287985

Casciaro, T., \& Piskorski, M. J. (2005). Power imbalance, mutual dependence, and constraint, absorption: a close look at resource dependence theory. Administrative Science Quarterly, 50(2), 167-199. doi: 10.2189/asqu.2005.50.2.167

Cho, T. S., \& Hambrick, D. C. (2006). Attention as the mediator between top management team characteristics and strategic change: the case of airline deregulation. Organization Science, 17(4), 453-469. doi: 10.1287/orsc. 1060.0192

Cohen, J. (1992). A power primer. Psychological Bulletin, 112(1), 155-159. doi: 10.1037/00332909.112.1.155

Cohen, J., Cohen, P., West, S. G., \& Aiken, L. S. (2003). Applied multiple regression/correlation analysis for the behavioral sciences. Mahwah, NJ: Erlbaum.

Crossland, C., \& Hambrick, D. C. (2007). How national systems differ in their constraints on corporate executives: a study of CEO effects in three countries. Strategic Management Journal, 28(8), 767789. doi: $10.1002 / \mathrm{smj} .610$

Dalton, D. R., Daily, C. M., Ellstrand, A. E., \& Johnson, J. L. (1998). Meta-analytic reviews of board composition, leadership structure, and financial performance. Strategic Management Journal, 19(3), 269-290. doi: 10.1002/(SICI)1097-0266(199803)19:3<269::AID-SMJ950>3.0.CO;2-K 
D’Aveni, R. A., \& Macmillan, I. C. (1990). Crisis and the content of managerial communications - a study of the focus of attention of top managers in surviving and failing firms. Administrative Science Quarterly, 35(4), 634-657. doi: 10.2307/2393512

Donaldson, T., \& Preston, L. E. (1995). The stakeholder theory of the corporation: concepts, evidence, and implications. Academy of Management Review, 20(1), 65-91. doi: 10.5465/AMR.1995.9503271992

Drees, J. M., \& Heugens, P. P. M. A. R. (2013). Synthesizing and extending resource dependence theory: a meta-analysis. Journal of Management, 39(6), 1666-1698. doi: 10.1177/0149206312471391

Duriau, V. J., Reger, R. K., \& Pfarrer, M. D. (2007). A content analysis of the content analysis literature in organization studies - research themes, data sources, and methodological refinements. Organizational Research Methods, 10(1), 5-34. doi: 10.1177/1094428106289252

Emerson, R. M. (1962). Power-dependence relations. American Sociological Review, 27(1), 31-41. doi: $10.2307 / 2089716$

Finkelstein, S. (1997). Interindustry merger patterns and resource dependence: a replication and extension of Pfeffer (1972). Strategic Management Journal, 18(10), 787-810. doi: 10.1002/(sici)1097-0266(199711)18:10<787::aid-smj913>3.0.co;2-r

Hung, S. C. (2005). The plurality of institutional embeddedness as a source of organizational attention differences. Journal of Business Research, 58(11), 1543-1551. doi: 10.1016/j.jbusres.2004.09.001

Jones, T. M. (1995). Instrumental stakeholder theory - a synthesis of ethics and economics. Academy of Management Review, 20(2), 404-437. doi: 10.5465/AMR.1995.9507312924

Levy, O. (2005). The influence of top management team attention patterns on global strategic posture of firms. Journal of Organizational Behavior, 26(7), 797-819. doi: 10.1002/job.340

Lindenberg, E. B., \& Ross, S. A. (1981). Tobin's q ratio and industrial organization. Journal of Business, 54(1), 1-32. doi: 10.1086/296120

Matten, D., \& Moon, J. (2008). "Implicit" and "explicit" CSR: a conceptual framework for a comparative understanding of corporate social responsibility. Academy of Management Review, 33(2), 404-424. doi: 10.5465/AMR.2008.31193458

Mitchell, R. K., Agle, B. R., \& Wood, D. J. (1997). Toward a theory of stakeholder identification and salience: defining the principle of who and what really counts. Academy of Management Review, 22(4), 853-886. doi: 10.5465/AMR.1997.9711022105

Ocasio, W. (1995). The enactment of economic adversity: a reconciliation of theories of failure induced change and threat-rigidity. In L. L. Cummings \& B. M. Staw (Eds.), Research in organizational behavior (Vol. 17, pp. 287-331). Greenwich: JAI Press.

Ocasio, W. (1997). Towards an attention-based view of the firm. Strategic Management Journal, 18(S1), 187-206. doi: 10.1002/(SICI)1097-0266(199707)18:1+<187::AID-SMJ936>3.0.CO;2-K

Ocasio, W., \& Joseph, J. (2005). An attention-based theory of strategy formulation: linking micro- and macroperspectives in strategy processes. Strategy Process, 22, 39-61. doi: 10.1016/S07423322(05)22002-8

Ocasio, W., \& Joseph, J. (2006). Governance channels and organizational design at General Electric: 1950-2001. In R. Burton, B. Eriksen, D. D. Hakonsson, \& C. C. Snow (Eds.), Organization design: the evolving state-of-art (pp. 267-284). New York: Springer. 
Pfeffer, J. (1981). Management as symbolic action: the creation and maintenance of organizational paradigms. Stanford: Graduate School of Business, Stanford University.

Pfeffer, J., \& Salancik, G. R. (1978). The external control of organizations: a resource dependence perspective. New York: Harper \& Row.

Reputation Institute. (2007). Company methodology: world's most respected companies. Retrieved January 9, 2009, from http://www.forbes.com/leadership/2007/05/21/reputation-institutesurveylead-citizen-cx_sm_0521methodology.html

Rindova, V. P., Becerra, M., \& Contardo, I. (2004). Enacting competitive wars: competitive activity, language games, and market consequences. Academy of Management Review, 29(4), 670-686. doi: 10.5465/AMR.2004.14497655

Segars, A. H., \& Kohut, G. F. (2001). Strategic communication through the World Wide Web: an empirical model of effectiveness in the CEO's letter to shareholders. Journal of Management Studies, 38(4), 535-556. doi: 10.1111/1467-6486.00248

Sonpar, K., \& Golden-Biddle, K. (2008). Using content analysis to elaborate adolescent theories of organization. Organizational Research Methods, 11(4), 795-814. doi: $10.1177 / 1094428106297804$

Staw, B. M., McKechnie, P. I., \& Puffer, S. M. (1983). The justification of organizational performance. Administrative Science Quarterly, 28(4), 582-600. doi: 10.2307/2393010

Sundaram, A. K., \& Inkpen, A. C. (2004). The corporate objective revisited. Organization Science, 15(3), 350-363. doi: $10.1287 /$ orsc. 1040.0068

Svenska Handelsbank. (2004). Annual report 2004. Retrieved from https://bib.kuleuven.be/files/ebib/jaarverslagen/SvenskaHandelsbanken_2004.pdf

The Walt Disney Company. (2004). Annual report 2004. Retrieved from http://thewaltdisneycompany.com/investors/annual_reports/2004/index.html

Thompson, J. D. (1967). Organizations in action; social science bases of administrative theory. New York: McGraw-Hill.

White, P. E. (1974). Resources as determinants of organizational behavior. Administrative Science Quarterly, 19(3), 366-379. doi: 10.2307/2391978

Yadav, M. S., Prabhu, J. C., \& Chandy, R. K. (2007). Managing the future: CEO attention and innovation outcomes. Journal of Marketing, 71(4), 84-101. doi: 10.1509/jmkg.71.4.84

\section{Author's Profile}

